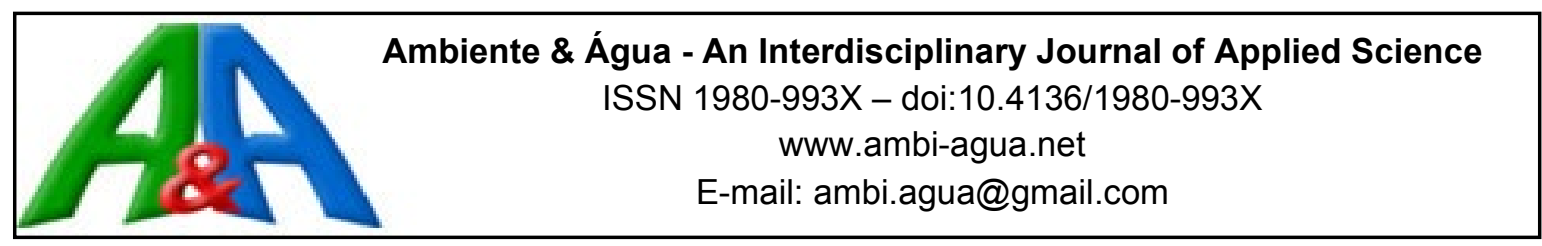

\title{
Effect of allowable flow-rate variation and local head loss on maximum length of non-pressure compensated drip tape
}

\author{
ARTICLES doi:10.4136/ambi-agua.2676
}

Received: 12 Nov. 2020; Accepted: 26 Feb. 2021

\begin{abstract}
Luiz Antonio de Andrade ${ }^{1}$; João Carlos Cury Saad ${ }^{2 *}$; Bruno Marcos Nunes Cosmo ${ }^{2}$; João Victor Costa ${ }^{2}$; Willian Aparecido Leoti Zanetti ${ }^{2}$

${ }^{1}$ Consultor autônomo. Alameda Frida Elza Scheuber Brantes, n 651, CEP: 18705-790, Avaré, SP, Brazil. E-mail: luiz.a.a@outlook.com

${ }^{2}$ Faculdade de Ciências Agronômicas. Departamento de Engenharia Rural e Socioeconomia. Universidade Estadual Paulista "Júlio de Mesquita Filho" (UNESP), Avenida Universitária, nº 3780, CEP: 18610-034, Botucatu, SP, Brazil. E-mail: brunomcosmo@gmail.com,jv.costa@unesp.br,willianleoti@gmail.com

*Corresponding author. E-mail: joao.saad@unesp.br
\end{abstract}

\begin{abstract}
A challenge for the design of drip irrigation systems with non-pressure compensated emitters is to increase the maximum length of the lateral lines without significantly reducing water application uniformity. This work evaluated the effect of the flow-rate variation and the local head loss in the maximum length of drip tape with a non-pressure compensated flat emitter. The tests were carried out in a laboratory, using a collapsible drip tape non-pressure compensated in three 50-meter segments. The production line was configured to generate drip tapes without insertion of emitters and with closed emitters $(0.30 \mathrm{~m}$ spacing $)$. The experimental local head loss was compared with the Darcy-Weisbach equation's estimates using the Blasius friction factor. In the sequence, simulations were generated for the flow-rate variations of 10 and $20 \%$ for the emitter spacings of $0.30,0.40$, and $0.50 \mathrm{~m}$. The results showed that the local head loss had little influence on the lateral line's maximum length, generating variations of $2.5 \%$ on average. However, increasing the allowable flow rate variation from 10 to $20 \%$ resulted in a 34\% increase in the lateral line maximum length. Also, the reduction in uniformity coefficients was less than $5 \%$, enabling the indexes to remain above $90 \%$. The adoption of higher flow rate variation values allowed gains in the lateral line length with a small decrease in uniformity, making it an alternative to reduce design and operational costs.
\end{abstract}

Keywords: emitter head loss, lateral line length, uniformity.

\section{Efeito da variação de vazão permitida e da perda de carga localizada no comprimento máxima de fita gotejadora não compensada}

\section{RESUMO}

Um desafio para o dimensionamento de sistemas de irrigação por gotejamento com emissores não compensados é aumentar o comprimento máximo das linhas laterais sem reduzir significativamente a uniformidade de aplicação de água. Este trabalho teve como objetivo avaliar o efeito da variação da vazão permitida e da perda de carga no emissor no comprimento máximo da linha lateral utilizando mangueira gotejadora com gotejador plano não compensado. 
Os ensaios foram realizados em laboratório, utilizando-se três segmentos de 50 metros de fita gotejadora não compensada. A linha de produção foi configurada para gerar fitas gotejadoras com as seguintes características: sem inserção de emissores; com emissores fechados (espaçamento de $0,30 \mathrm{~m}$ ). A perda de carga local obtida experimentalmente foi comparada com as estimativas da equação de Darcy-Weisbach usando o fator de atrito de Blasius. Na seqüência foram geradas simulações para as variações da vazão de 10 e $20 \%$, para os espaçamentos entre emissores de 0,$30 ; 0,40$; e $0,50 \mathrm{~m}$. A perda de carga localizada teve pouca influência no comprimento máximo da linha lateral, gerando variações médias de $2,5 \%$. No entanto, o aumento da variação da vazão permitida de 10 para $20 \%$ resultou em um aumento de $34 \%$ no comprimento máximo da linha lateral. Além disso, a redução dos coeficientes de uniformidade avaliados foi inferior a 5\%, permitindo que os índices permanecessem acima de $90 \%$. A adoção de maiores valores de variação da vazão permitiu ganhos no comprimento da linha lateral com uma pequena diminuição na uniformidade, tornando-se uma alternativa para otimização do dimensionamento de fitas gotejadoras não compensadas.

Palavras-chave: gotejamento, linha lateral, uniformidade.

\section{INTRODUCTION}

Micro irrigation systems apply dripping water slowly to the root systems of plants, either directly near the root zone or onto the soil surface (Baiamonte, 2018). The drip tape emitters can be pressure-compensated or non-pressure-compensated. The compensated drippers provide a constant flow rate under pressure variations along the lateral line, allowing longer lengths, but they are more expensive. Using non-pressure compensating emitters, the flow rate decreases as the pressure is reduced, resulting in shorter lateral lines to obtain the desired uniformity (Ludwig and Saad, 2013).

Lay-flat drip tapes with non-pressure compensated emitters are widely used to irrigate field crops and seasonal horticultural crops due to their high application efficiency and uniformity, ease of installation, and low investment cost (Provenzano et al., 2014; Wang et al., 2020). The limitation is that, due to head loss, the lateral line length must be short to maintain uniformity, even when installed in level ground conditions.

The determination of the lateral line's maximum length is essential in optimizing the drip irrigation system cost (Miranda et al., 2017). Longer drip lines reduce installation costs compared to a set of shorter drip lines that total the same length (Gomes et al., 2010). Complementing the economic advantage, the smaller number of lines, due to the greater length, represents a gain in practicality in handling, as long as they are adequately sized to ensure uniformity to the system (Gomes, 2013).

To optimize the maximum length of the lateral lines in non-pressure compensated drippers, some suggested options are to employ emitters with a lower manufacturing variation coefficient (Katsurayama, 2015) and to adequately choose the allowed flow variation (Perboni et al., 2015).

Since the drip tape with non-pressure compensated flat dripper predominates in horticultural irrigation in Brazil due to the lower initial cost than compensated hoses, it would be useful to evaluate the flow-rate variation effect in the lateral line length and also the uniformity as optimization strategies.

The design of drip hose lateral lines considers a maximum flow variation of $10 \%$ (Karmeli and Keller, 1975). However, some authors recommend higher values, between 10 and 20\%, as is the case with Sammis and $\mathrm{Wu}(1985)$, or even 20\%, in supplementary irrigation (Bernardo et al., 2019). Wu (1997) indicates that the flow variation between emitters on one side can be increased by up to $30 \%$, unlike the usual 10 to $20 \%$, which still obtains a uniformity coefficient of water application above $80 \%$, since the manufacturing variation coefficient is less than $10 \%$. 
However, a proper hydraulic design of drip tape lateral line requires an accurate evaluation of the emitter properties, the friction head loss in pipes, and the local head loss induced by the presence of emitters (Demir et al., 2007; Wang and Chen, 2020; Flores et al., 2021). Yildirim (2007) showed that neglecting the local head loss's impact may lead to an error of $7 \%$ in the lateral line length for labyrinth and orifice vortex online emitter models. Gomes et al. (2010) found that the maximum lateral length was overestimated by $9.5 \%$ when the local head loss of the coaxial emitter integrated into polyethylene pipes was not considered.

Although the flat emitter is the most-used model in non-pressure compensated drip tapes, there is little information about the local head loss and its effect on the lateral line maximum length.

This work evaluated the effect of the flow-rate variation and the local head loss in the maximum length of drip tape with a non-pressure compensated flat emitter.

\section{MATERIALS AND METHODS}

The tests to measure the local hose head loss were carried out at the Petroisa Hydraulic Laboratory, in partnership with FCA - Campus de Botucatu - UNESP. A collapsible drip tape (CDT) consisting of polyethylene resins with the manufacturer's technical specifications shown in Table 1 was used to carry out the study.

Table 1. Drip tape characteristics.

\begin{tabular}{lc}
\hline Parameters & Values \\
\hline Wall thickness & $0.250 \mathrm{~mm}$ \\
Operational pressure head & $10 \mathrm{mca}$ \\
Nominal diameter & $16 \mathrm{~mm}$ \\
Internal diameter at $10 \mathrm{mca}$ & $16.2 \mathrm{~mm} \pm 0.3 \mathrm{~mm}$ \\
Flow rate at operational pressure & $1.474 \mathrm{~L} \mathrm{~h}^{-1}$ \\
Burst pressure head & $25 \mathrm{mca}$ \\
Smallest dripper pass dimensions & $0.48 \times 0.55 \mathrm{~mm}$ \\
Emitter spacing variation & Nominal $\pm 5 \%$ \\
Discharge coefficient, $k$ (Equation 1$)$ & 0.46297 \\
Emitter flow exponent, $x$ (Equation 1$)$ & 0.503 \\
Manufacturing variation coefficient, $C V_{m}$ & 0.0353
\end{tabular}

The nominal pressure-discharge curve for the emitter is given by Equation 1: $q=k H^{x}$

Where $q$ is the emitter discharge $\left(\mathrm{L} \mathrm{h}^{-1}\right), k$ is the discharge coefficient, $H$ is the emitter's pressure head (mca), and $x$ is the emitter flow exponent.

For the proposed research, the manufacturer configured the production line to generate drip tapes with the following characteristics: a) hose without insertion of emitters, and b) hose with $0.30 \mathrm{~m}$-spaced emitters but without exit hole. In case $b$, the dripper hose production line has been configured so that the machine does not perform the drilling corresponding to the dripper's water outlet, producing a hose with closed drippers.

The tests used a level platform located $1.5 \mathrm{~m}$ above the ground, with a maximum total 
length of $250 \mathrm{~m}$. The hydraulic network consisted of a 1,000 L water tank, a motor pump with a flow rate of $87.84 \mathrm{~m}^{3} \mathrm{~h}^{-1}$, and pressure up to $60 \mathrm{mca}$. For filtering the water, 110 -micron plastic disc filters were used. A frequency inverter, three-needle registers, and two drawer registers were used to control pressure and flow. To collect water from the emitters, a galvanized steel channel installed $0.3 \mathrm{~m}$ below the platform support in its entire length was used, allowing the waters return to the box.

An electromagnetic flow meter and a transmitter were used to measure the flow rate, without moving parts, brand INCONTROL, Series VMS-012, with a diameter of $13 \mathrm{~mm}$, and a Totalizing Indicator, Model MEV-100. In the calibration of the equipment, water at $22^{\circ} \mathrm{C}$ was used, generating an accuracy of $\pm 2 \%$ in the flow range between 120 to $4,070 \mathrm{~L} \mathrm{~h}^{-1}$.

In the pressure measurement, an electronic manometer with an integrated silicon pressure sensor, Model MPX 5500, manufactured by Freescale Semiconductor Inc, was used, with a precision of $0.01 \mathrm{mca}$ in the range of 0 to $12 \mathrm{mca}$, associated with a Microprocessed Electronic Indicator, Model HW 7000, manufactured by Coelmatic Ltda. During the tests, the water temperature was monitored by a digital contact thermometer.

The drip tape was subjected to a pressure head of $10 \mathrm{mca}$ in 10 samples to determine the external diameter, and a Mitoyo electronic micrometer was used in four positions equidistant across. The same places were used to determine the hose wall's thickness without pressurization to obtain the drip tape's internal diameter $(D)$.

The emitter's internal diameter $(D g)$ was obtained through the difference between $D$ and the emitter height plus the hose wall where it was integrated. The hose area's determinations with the emitter $(A c)$ and without the emitter $(A s)$ were carried out using the Computer Assisted Design (CAD) program.

The head loss was evaluated in three 50-meter segments for each type of drip tape manufacturing, with three repetitions, maintaining the inlet pressure at 10 mca throughout the test. The flow rates were evaluated and corresponded to velocity ranging from 0.16 to 0.94 $\mathrm{m} \mathrm{s}^{-1}$, with a Reynolds' number between 2,500 and 14,400.

The method of estimating the emitter's local head loss was based on the Obstruction Index - OI (Alves and Porto, 2002; Cardoso and Klar, 2014), according to Equations 2, 3, and 4.

$$
\begin{aligned}
& r=\frac{A c}{A s} \\
& I O=\frac{(1-r)^{2}}{r^{2}}=\theta \\
& h f e_{i}=\frac{(1-r)^{2} V_{i}^{2}}{r^{2} 2}
\end{aligned}
$$

Where $h f e_{i}$ is the local head loss in the emitter $i$, mca; $r$ is the ratio between $A c$ and $A s ; V_{i}$ is the average water velocity at uniform pipe section near the emitter $i, \mathrm{~m} \mathrm{~s}^{-1}$.

The experimental results of head loss were compared with those obtained by the DarcyWeisbach equation (universal) with friction factor (f) from Blasius' formula.

In the level lateral line, the maximum pressure is the pressure at the inlet $\left(H_{0}\right)$ of the drip tape, which was adopted as the nominal operating pressure recommended by the manufacturer (10 mca). The minimum pressure $\left(H_{\min }\right)$ is at the end of the line, where the emitter with the lowest flow rate is positioned. The total head loss $\left(H f_{L}\right)$ is the difference between the maximum pressure and the minimum pressure $\left(H f_{L}=H_{\max }-H_{\min }\right)$.

Substituting in Equation 5, proposed by Keller and Karmeli (1974), the allowable flow variation $(\Delta q)$ in the lateral line and the value of $x$ provided by the manufacturer, the permissible pressure variation $(\Delta H)$ is obtained (Wu and Yue, 1993). The minimum pressure is obtained by 
replacing $H_{\max }$ and $\Delta H$ in Equation 6. The average pressure $\left(H_{a v}\right)$ is determined by Equation 7 (Howell and Hiler, 1974).

$$
\begin{gathered}
\Delta H=1-(1-\Delta q)^{\frac{1}{x}} \\
\Delta H=\frac{H_{\max }-H_{\min }}{H_{\max }} \\
H_{a v}=H_{0}-0.75 H f_{L}
\end{gathered}
$$

Once the maximum and minimum pressures are defined, there is only one possible length for the level drip tape, and it can be obtained using an electronic spreadsheet. The last emitter (emitter number 1) has the minimum pressure on the lateral line. The penultimate emitter is number 2, and so on until emitter $N$, located at the tape's inlet where the maximum pressure occurs (Figure 1).
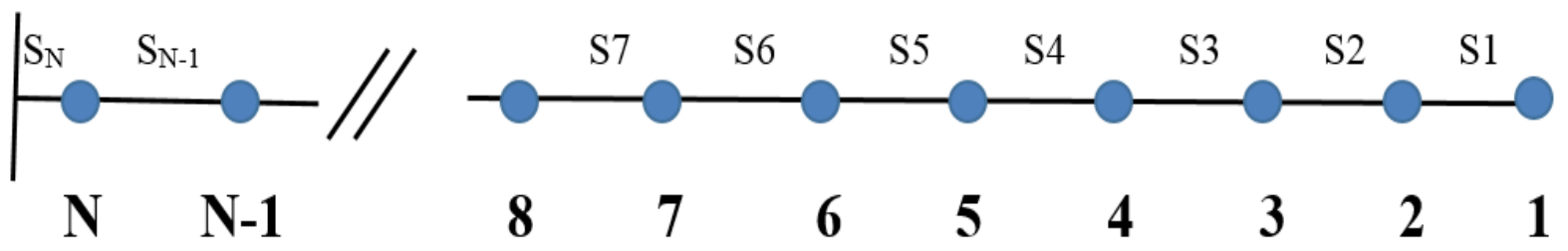

Figure 1. Drip tape lateral line with multiple, equally spaced outlets.

The flow in the segment between emitters 1 and 2 is obtained by applying Equation 1 for dripper 1. This flow rate value is used to calculate the head loss in the tape section between these two emitters, and the corresponding velocity is applied to define the $h f_{e}$ in emitter 1 . The section head loss and $h f_{e}$ are added to the pressure head of the emitter 1 providing the working pressure of the emitter 2. The sum of the flow rates of emitters 1 and 2 provides the flow rate in the section between emitters 2 and 3 . The pressure at emitter 3 is the sum of the pressure at emitter 2 plus the local head loss at emitter 2, plus the pressure loss in the section between emitters 2 and 3. This step-by-step method is repeated until the working pressure equal to 10 mca is reached in the emitter $\mathrm{N}$.

The lateral line total length, $L$, in meters is given by Equation 8:

$L=(N-1) S_{e}$

Where: $N=$ total number of drippers in the lateral line; $S_{e}=$ dripper spacing, in $\mathrm{m}$.

The total head loss, $h f_{L}$, in mca, is estimated by Equation 9:

$h f_{L}=\sum_{i=1}^{N}\left(h f_{i}+h f e_{i}\right)$

Where: $h f_{i}=$ head loss in section $i$, in mca; and $h f e_{i}=$ local head loss in emitter i, in mca.

The pressure head at dripper $i, H_{i}$, in mca, is given by Equation 10:

$H_{i}=H_{i-1}+h f_{i}+h f e_{i}$

The sum of the flow rates of all emitters from 1 to $\mathrm{N}$ provides the flow rate into the lateral line $\left(Q_{0}\right)$ Equation 11: 


$$
Q_{0}=\sum_{i=1}^{N} q_{i}
$$

Where: $q_{i}=$ emitter $i$ discharge, in $\mathrm{L} \mathrm{h}^{-1}$.

The average flow rate $\left(q_{a v}\right)$ was calculated by dividing the sum of the flow rates of all lateral line emitters by the number of emitters. Its location was obtained in the spreadsheet identifying the number of the emitter with the corresponding rate value.

From this procedure, simulations were generated for the flow-rate variations of 10 and $20 \%$ in the lateral line, for emitter spacings of $0.30,0.40$, and $0.50 \mathrm{~m}$.

To evaluate the drip-tape design, the following uniformity indexes (Equations 12, 13 and 14) were estimated: a) EU $U_{C V m}$, emission uniformity coefficient defined by Keller and Karmeli (1974) and recommended by the EP405.1 standard (Asabe, 2003); b) $E U_{D}$, the design emission uniformity coefficient, described by Nakayama et al. (1979); and c) $E U_{B}$, the revised emission uniformity coefficient presented by Barragan et al. (2006).

$$
\begin{aligned}
& E U_{C V_{m}}=100 \cdot\left(1-\frac{1.27 C V_{m}}{\sqrt{N_{e}}}\right) \cdot\left(\frac{H_{\min }}{H a v}\right)^{x} \\
& E U_{D}=100 \cdot\left(1-\frac{0.798 C V_{m}}{\sqrt{N_{e}}}\right) \\
& E U_{B}=100 \cdot\left[1-\sqrt{\left(1-\left(\frac{H_{\min }}{H_{a v}}\right)^{x}\right)^{2}+\left(\frac{1.27 C V_{m}}{\sqrt{N_{e}}}\right)^{2}}\right]
\end{aligned}
$$

Where $N_{e}$ is the number of emitters from which each plant receives water.

\section{RESULTS AND DISCUSSION}

\subsection{Experimental data}

The average geometric characteristics of the drip tape, measured in 10 samples for the operating pressure of $10 \mathrm{mca}$, corresponded to a wall thickness $(E p)$ of $0.248 \mathrm{~mm}$, free internal Diameter $(D)$ of $16.232 \mathrm{~mm}$, inner diameter with emitter $(D g)$ of $13.147 \mathrm{~mm}$, cross-sectional area of the hose with emitter $(A c)$ of $188.73 \mathrm{~mm}^{2}$, cross-sectional area of the hose without the Emitter $(A s)$ of $207.54 \mathrm{~mm}^{2}$, and coefficient of the variation of $1.61 \%$. The ratio $(r)$ between $A c$ and $A s$ was 0.9094 .

When pressurized at $10 \mathrm{mca}$, the $D$ and the $E p$ values were within the range indicated by the manufacturer. The experimental results for the unit head loss test $(J)$, caused by the drip tape without the presence of emitters, and the unit head loss estimate using the Darcy-Weisbach equation with the friction factor estimated by Blasius' formula are shown in Table 2.

The unit head losses for the tape with closed emitters obtained with the Darcy-Weisbach equation using the friction factor calculated by the Blasius formula, for different drip-tape flow rates, were very close to those obtained under the experimental conditions. It is in agreement with results obtained by Yasmina and Rachid (2015), Flores (2017), Miranda et al. (2018), and Melo (2020). The data obtained from Darcy-Weisbach equation with Blasius were adjusted and generated Equation 15. It was applied in the electronic spreadsheet to define the maximum length of the drip tape lateral line in the simulation process. 
Table 2. Experimental unit head loss $(J)$ for drip tape without emitters, and for drip tape with closed emitters (drippers having no exit hole); local head loss (hfe), and pressure head loss in the tape without emitters estimated by the Darcy-Weisbach equation using the Blasius formula according to the drip tape flow rate (drippers spacing $0.32 \mathrm{~m}$, internal diameter considered $0.016232 \mathrm{~m}$, and absolute roughness of $0.00001 \mathrm{~m}$ and water temperature at $20^{\circ} \mathrm{C}$ ).

\begin{tabular}{ccccc}
\hline & \multicolumn{3}{c}{ Experimental } & Theoretical \\
\cline { 2 - 3 } $\begin{array}{c}\text { Drip tape flow } \\
\text { rate }\left(\mathrm{L} \mathrm{h}^{-1}\right)\end{array}$ & \multicolumn{2}{c}{ Unit head loss, $J(\mathrm{~m} / \mathrm{m})$} & $\begin{array}{c}\text { Local head loss in the } \\
(\mathrm{m} / \mathrm{m})\end{array}$ \\
\cline { 2 - 3 } & $\begin{array}{c}\text { Drip tape with closed } \\
\text { emitters }(a)\end{array}$ & $\begin{array}{c}\text { Tape without } \\
\text { drippers }(b)\end{array}$ & $\begin{array}{c}\text { dripper, } h f e(\mathrm{~m})(c) \\
\text { D.W. }{ }^{*} \text { with } \\
\text { Blasius }\end{array}$ \\
\hline 699.05 & 0.08484 & 0.07652 & $0.00266^{* *}$ & 0.08066 \\
600.47 & 0.06630 & 0.06134 & 0.00159 & 0.06182 \\
500.83 & 0.05017 & 0.04604 & 0.00132 & 0.04500 \\
398.01 & 0.03510 & 0.03351 & 0.00051 & 0.03010 \\
299.43 & 0.02320 & 0.02222 & 0.00043 & 0.01829 \\
199.79 & 0.01339 & 0.01203 & 0.00031 & 0.00901 \\
\hline
\end{tabular}

${ }^{*}$ D.W. Darcy-Weisbach equation with friction factor calculated by Blasius formula; ${ }^{* *} c=(a-b) /\left(1 / S_{\mathrm{e}}\right)$, where $S_{e}$ is the emitter spacing, $\mathrm{m}$.

$$
J=8.512 \cdot 10^{-7} \cdot Q^{1.75} \quad R^{2}=0.9999
$$

Where $J$ is the unit head loss, $\mathrm{m} \mathrm{m}^{-1} ; Q$ is the drip-tape flow rate, in $\mathrm{L} \mathrm{h}^{-1}$.

Using the methodology (Equation 4) proposed by Alves and Porto (2002) and the drip tape characteristics $c, A s$, and $r$, Equation 16 was presented, representing the local head loss ( $h f e$ ) caused by the emitter's insertion in the drip tape.

$$
h f_{e}=0.009933 \cdot \frac{V^{2}}{2 \cdot g}
$$

\subsection{Simulations}

To evaluate the effect of the flow rate variation on the drip tape length, minimum pressure values were generated according to the $\mathrm{Wu}$ and Yue (1993) equation, depending on the allowable flow variation (Sammis and $\mathrm{Wu}, 1985$ ) and also on the allowable total head loss for the evaluated tape. This procedure generated the following results: for $x$ equal to 0.503 and inlet pressure of $10 \mathrm{mca}$ (working pressure recommended by the manufacturer), with a flow-rate variation of $10 \%$, there was a head loss $\left(H f_{L}\right)$ of 1.89 mca (minimum pressure of 8.11 and maximum of $10 \mathrm{mca}$ ), while for the same conditions with $20 \%$ flow variation, there was a head loss of 3.58 mca (minimum pressure of 6.42 and maximum of $10 \mathrm{mca}$ ).

The maximum lateral line length therefore was determined for the dripper spacings of 0.2 , 0.3, 0.4, and 0.5m using Equations 5 and 15, and disregarding the local head loss due to the emitters. The same determination was done considering the local head loss due to the emitter obtained by Equation 16. For both cases, the step-by-step method was used. The results are shown in Table 3.

Comparing the results of Table 3 , the head loss generated by reducing the water passage area by the insertion of the emitter influenced $2.5 \%$, on average, in the maximum lateral line length, ranging from 2.1 to $2.9 \%$. This small difference reflects a low value of local head loss due to the emitter's insertion in the drip tape (Prado et al., 2014). The small interference of $h f e$ is associated with the high value of the ratio $(r)$ between the areas of the hose with $(A c=188.73$ $\left.\mathrm{mm}^{2}\right)$ and without emitter $\left(A s=207.54 \mathrm{~mm}^{2}\right)$, which was of 0.9094 . The emitters caused a small 
disturbance in the water flow in the hose and, consequently, small values of local head loss.

Table 3. Drip tape characteristics, in different spacing between emitters, for $10 \%$ and $20 \%$ flow rate variations, not considering and considering local head loss due to the emitter.

\begin{tabular}{|c|c|c|c|c|c|c|c|c|}
\hline \multicolumn{9}{|c|}{ Not considering local head loss due to the emitter $(h f e)$} \\
\hline \multirow{3}{*}{ Parameters } & \multicolumn{8}{|c|}{ Emitter spacing $(\mathrm{cm})$} \\
\hline & \multicolumn{2}{|c|}{20} & \multicolumn{2}{|c|}{30} & \multicolumn{2}{|c|}{40} & \multicolumn{2}{|c|}{50} \\
\hline & $10 \%$ & $20 \%$ & $10 \%$ & $20 \%$ & $10 \%$ & $20 \%$ & $10 \%$ & $20 \%$ \\
\hline$Q_{0}, \mathrm{~L} \mathrm{~h}^{-1}$ & 597.2 & 739.6 & 516.7 & 638.9 & 464.7 & 576.0 & 429.2 & 530.5 \\
\hline $\mathrm{L}, \mathrm{m}$ & 87.2 & 117.2 & 113.1 & 151.8 & 135.6 & 182.4 & 156.5 & 210.0 \\
\hline Drippers number & 437 & 587 & 378 & 507 & 340 & 457 & 314 & 421 \\
\hline$q_{a v}, \mathrm{~L} \mathrm{~h}^{-1}$ & 1.37 & 1.26 & 1.37 & 1.26 & 1.37 & 1.26 & 1.37 & 1.26 \\
\hline$q_{a v}$ position, $\mathrm{m}$ & 33.4 & 45.0 & 42.9 & 58.5 & 52.0 & 70.4 & 60.0 & 81.0 \\
\hline$q_{a v}$ position, $\%$ & 38.30 & 38.4 & 37.93 & 38.54 & 38.35 & 38.60 & 38.34 & 38.57 \\
\hline$H_{a v}, \mathrm{mca}$ & 8.61 & 7.35 & 8.61 & 7.35 & 8.61 & 7.37 & 8.61 & 7.35 \\
\hline$\%$ de $H f$ until $q_{a v}$ & 74.11 & 74.81 & 74.01 & 74.99 & 74.20 & 75.07 & 74.20 & 75.05 \\
\hline \multicolumn{9}{|c|}{ Considering local head loss due to the emitter (hfe) } \\
\hline \multirow{3}{*}{ Parameters } & \multicolumn{8}{|c|}{ Emitter spacing $(\mathrm{cm})$} \\
\hline & \multicolumn{2}{|c|}{20} & \multicolumn{2}{|c|}{30} & \multicolumn{2}{|c|}{40} & \multicolumn{2}{|c|}{50} \\
\hline & $10 \%$ & $20 \%$ & $10 \%$ & $20 \%$ & $10 \%$ & $20 \%$ & $10 \%$ & $20 \%$ \\
\hline$Q_{0}, \mathrm{~L} \mathrm{~h}^{-1}$ & 580.9 & 718.3 & 505.8 & 621.2 & 453.8 & 560.8 & 418.2 & 518.0 \\
\hline$L, \mathrm{~m}$ & 84.8 & 113.8 & 110.7 & 147.6 & 132.4 & 177.6 & 152.5 & 205.0 \\
\hline Drippers number & 425 & 570 & 370 & 493 & 332 & 445 & 306 & 411 \\
\hline$q_{a v}, \mathrm{~L} \mathrm{~h}^{-1}$ & 1.37 & 1.26 & 1.37 & 1.26 & 1.37 & 1.26 & 1.37 & 1.26 \\
\hline$q_{a v}$ position, $\mathrm{m}$ & 32.4 & 43.8 & 42.6 & 68.4 & 50.8 & 68.4 & 58.5 & 79.00 \\
\hline$q_{a v}$ position, $\%$ & 38.2 & 38.49 & 38.48 & 38.51 & 38.37 & 38.51 & 38.36 & 38.54 \\
\hline$H_{a v}, \mathrm{mca}$ & 8.60 & 7.32 & 8.60 & 7.32 & 8.60 & 7.32 & 8.60 & 7.32 \\
\hline$\%$ de $H f$ until $q_{a v}$ & 73.78 & 74.79 & 73.98 & 74.79 & 73.88 & 74.79 & 73.96 & 74.76 \\
\hline
\end{tabular}

However, Laperuta Neto et al. (2011) obtained local head for tablet type emitters in a hose with an average diameter of $14.45 \mathrm{~mm}$ in the order of $23 \%$ of the total head loss. The emitter labyrinth configuration and its dimensions determine the interference degree in the flow and the magnitude of the local head loss (Gomes et al., 2010; Cardoso and Klar, 2014).

Figure 2 shows the maximum length of the drip tape with and without the emitters' insertion for 10 and $20 \%$ flow-rate variations.

The uniformity coefficients obtained for the drip tape for the spacings of 30, 40, and 50 $\mathrm{cm}$, with flow rate variations of 10 and $20 \%$, are shown in Table 4 . The flow-rate variation of $20 \%$ generated uniformity indexes greater than $90 \%$, in all evaluated combinations considered adequate by the ASAE EP405.1 standard (Asabe, 2003). Corroborating these results, Santos et al. (2013) found uniformity coefficients above 80 and 90\%, classified as good and excellent, respectively, for a $25 \%$ flow-rate variation.

Associating the information in Figure 2 with Table 4, it is observed that the increase in the flow-rate variation from 10 to $20 \%$ generates significant increases in the lateral line maximum length, with a small reduction in uniformity, which demonstrates an alternative of optimization in the project cost. Similar results were obtained by Frizzone et al. (1998), evaluating pressure compensated emitters spaced $0.3 \mathrm{~m}$. They observed that the flow variation of $20 \%$ generates increments in the order of $30 \%$ in the length of the lateral line in level comparatively to $10 \%$, for inlet pressures from 2 to $10 \mathrm{mca}$.

Mantovani et al. (2009) and Prado et al. (2014) found that the inlet pressure in the lateral 
line has a significant participation in the uniformity of water application and recommended the value of 10 mca for the drip irrigation system.

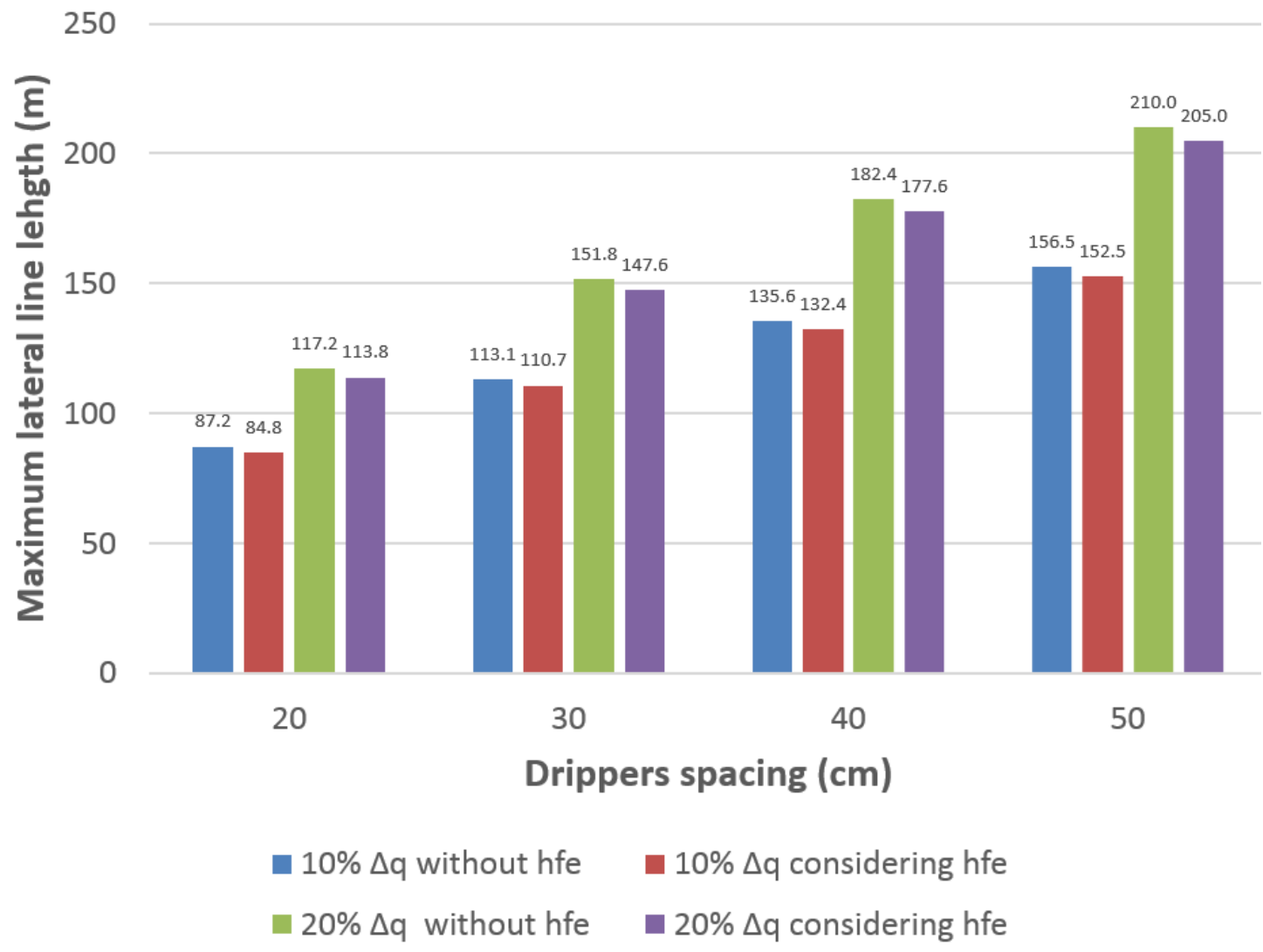

Figure 2. Drip tape maximum length for 10 and $20 \% \Delta q$, considering and not considering the local head loss caused by the emitters (hfe).

Table 4. Emission uniformity coefficients (\%), for $10 \%$ and $20 \%$ of discharge variation $(\Delta q)$ and emitter spacings of 10,20 , and $30 \mathrm{~cm}$.

\begin{tabular}{ccccccc}
\hline & \multicolumn{4}{c}{ Uniformity values (\%) } \\
\cline { 2 - 7 } Emission uniformity indexes & \multicolumn{3}{c}{$\Delta q=10 \%$} & \multicolumn{4}{c}{$\Delta q=20 \%$} \\
\cline { 2 - 7 } & \multicolumn{1}{c}{ Drippers spacing(m) } & \multicolumn{3}{c}{ Drippers spacing (m) } \\
\cline { 2 - 7 } & 0.30 & 0.40 & 0.50 & 0.30 & 0.40 & 0.50 \\
\hline$E U_{C V m}$ & 94.7 & 94.3 & 94.0 & 91.3 & 91.0 & 90.7 \\
$E U_{D}$ & 98.5 & 98.2 & 98.0 & 95.1 & 94.9 & 94.8 \\
$E U_{B}$ & 96.2 & 95.9 & 95.7 & 93.2 & 93.0 & 92.9 \\
\hline
\end{tabular}

\section{CONCLUSIONS}

According to the results obtained for the experimental conditions, it was concluded that the local head loss due to the flat emitters of the non-pressure compensated drip tape was small for all spacings and flow-rate variations evaluated, influencing $2.5 \%$, on average, in the lateral line maximum length.

The increase in the flow-rate variation from $10 \%$ to $20 \%$ allowed an increase of $34 \%$ in the lateral line maximum length, showing a reduction of the emission uniformity coefficients in the order of $5 \%$ but maintaining uniformity above $90 \%$ in all conditions evaluated.

The adoption of a higher flow-rate variation value, from 10 to $20 \%$, allowed gains in the 
lateral line length with a small decrease in uniformity, representing an alternative to reduce investment and operational costs.

\section{REFERENCES}

ALVES, P. R. V.; PORTO R. M. Coeficiente geométrico para estimativa de perda de carga localizada em linhas laterais de irrigação por gotejamento. Engenharia Agrícola, v. 22, n. 1, p. 51-59, 2002.

ASABE. ASAE EP405.1: Design and installation of microirrigation systems. St. Joseph, 2003. $6 p$.

BARRAGAN, J.; BRALTS, V.; WU, I. P. Assessment of emission uniformity for microirrigation design. Biosystems Engineering, v. 93, n. 1, p.89-97, 2006.

BAIAMONTE, G. Advances in designing drip irrigation laterals. Agricultural Water Management, v. 199, p.157-174, 2018.

BERnARdo, S.; MANTOVAni, E. C.; SILVA, D. D. da; SOARES, A. A. Manual de irrigação. 9. ed. Viçosa, Editora UFV, 2019. 545p.

CARDOSO, G. G. G.; KLAR, A. E. Índice geométrico e perda de carga localizada em conexões de emissores “online”. Engenharia Agrícola, Jaboticabal, v.34, n.6, p.1114-1127, 2014.

DEMIR, V.; YURDEM, H.; DEGIRMENCIOGLU, A. Development of prediction models for friction losses in drip irrigation laterals equipped with integrated in-line and on-line emitters using dimensional analysis. Biosystems Engineering, v. 96, n. 4, p. 617-631, 2007. https://doi.org/10.1016/j.biosystemseng.2007.01.002

FLORES, J. H. N. Modelagem matemática da perda de carga em emissores integrados a tubulação de irrigação localizada. 2017. 93f. Dissertação (Mestrado em Recursos Hídricos) - Universidade Federal de Pelotas, Pelotas, 2017.

FLORES, J. H. N.; FARIA, L. C.; RETTORE NETO, O.; DIOTTO, A. V.; COLOMBO, A. Methodology for determination the emitter local head loss in drip irrigation systems. Journal of Irrigation and Drainage Engineering, v. 147, n. 1, 2021. https://doi.org/10.1061/(ASCE)IR.1943-4774.0001516

FRIZZONE, J. A.; VIEIRA, A. T.; PAZ, V. P. S.; BOTREL, T. A. Caracterização Hidráulica de um Tubo Gotejador. Revista Brasileira de Engenharia Agrícola e Ambiental, v. 2, n. 3, p. 278-283, 1998.

GOMES, A. W. A.; FRIZZONE, J. A.; RETTORE NETO, O.; MIRANDA, J. H. Perda de carga localizada em gotejadores integrados em tubos de polietileno. Engenharia Agrícola, v. 30, n. 3, p. 435-446, 2010.

GOMES, H. P. Sistemas de irrigação: Eficiência energética. João Pessoa: Editora da UFPB, 2013. 281p.

HOWELL, T. A.; HILER, E. A. Trickle irrigation lateral design. Transactions of the ASAE, v. 17, n. 5, p.902-908, 1974.

KARMELI, D.; KELLER, J. Trickle irrigation design. Glendora: Rain Bird Sprinkler Manufacturing, 1975. 
KATSURAYAMA, G. T. Metodologia para dimensionamento do intervalo de operação de linhas laterais de microirrigação com emissores do tipo microtubo. 2015. 53f. Dissertação (Mestrado em Ciências) - Universidade de São Paulo, Escola Superior de Agricultura "Luiz de Queiroz", Piracicaba, 2015.

KELLER, J.; KARMELI, D. Trickle Irrigation design parameters. Transactions of the ASAE, v. 17, n. 4, p. 678-684, 1974.

LAPERUTA NETO, J.; CRUZ, R. L.; LAPERUTA FILHO, J.; PLETSCH, T. A. Perda de carga em mangueiras gotejadoras novas e usadas. Irriga, Botucatu, v.16, n.3, p.329-338, 2011.

LUDWIG, R.; SAAD. J. C. C. Increasing the Lateral Line Length of Drip Irrigation Systems. British. Journal of Environment \& Climate Change, v. 3, p. 499-509, 2013.

MANTOVANI, E. C.; BERNARDO, S.; PALARETTI, L. F. Irrigação: Princípios e métodos. 3. edd. Viçosa: UFV, 2009. 355 p.

MELO, V. G. M. L. Perda de carga em tubos gotejadores colapsáveis para microirrigação. 2020. 69f. Dissertação (Mestrado em Ciências) - Universidade de São Paulo, Escola Superior de Agricultura "Luiz de Queiroz”, Piracicaba, 2020.

MIRANDA, E. P.; ROMÁN, R. M. S.; SILVA, M. G.; FERNANDES, C. N. V.; SILVA, A. R. A. CmaxiLL - Algoritmo computacional para determinação do comprimento máximo da linha lateral em sistema de irrigação localizada. In: INOVAGRI INTERNATIONAL MEETING, 4., 2017, Fortaleza. Anais[...] Fortaleza: Inovagri, 2017. p.1-9.

MIRANDA, E. P.; ROSAL, G. B.; LIMA, F. U. Diferenças entre o Método Trecho-a-Trecho e o Método de Múltiplas Saídas na determinação das perdas de carga em uma linha lateral de um sistema de irrigação localizada. Revista Brasileira de Gestão Ambiental e Sustentabilidade, v.5, n.11, p.911-918, 2018.

NAKAYAMA, F. S.; BUCKS, D. A.; CLEMMENS, A. J. Assessing trickle emitter application uniformity. Transaction of the ASAE, v. 22, n. 4, p. 816-821, 1979.

PERBONI, A.; FRIZZONE, J. A.; JOSÉ, J. V.; ROCHA, H. S.; ALMEIDA, B. M. Coeficiente de carga cinética para gotejadores "in-line" do tipo cilíndrico. Irriga, v. 20, n. 1, p. 165$176,2015$.

PRADO, G.; NUNES, L. H.; TINOS, A. C. Avaliação técnica de dois emissores empregados na irrigação localizada. Revista Brasileira de Agricultura Irrigada, v. 8, n. 1, p. 12-35, 2014.

PROVENZANO, G.; DI DIO, P.; LEONE, R. Assessing a local losses evaluation procedure for low-pressure lay-flat drip laterals. Journal of Irrigation and Drainage Engineering, v. 140, p. 1-7, 2014. http://dx.doi.org/10.1061/(ASCE)IR.1943-4774.0000731

SAMMIS, T. W.; WU, I. P. Crop yield as affected by irrigation. In: INTERNATIONAL DRIP/ TRICKLE IRRIGATION CONGRESS, 3., 1985, Fresno. Anais... Fresno: ASAE, 1985. p.22-28.

SANTOS, C. S; SANTOS, D. P.; SILVA, P. F.; ALVES, E. S.; SANTOS, M. A. L. Avaliação da uniformidade de distribuição de um sistema de irrigação por gotejamento. Revista Verde de Agroecologia e Desenvolvimento Sustentável, v. 8, n. 3, p. 10-16, 2013. 
WANG, J.; CHEN, R. An improved finite element model for the hydraulic analysis of drip irrigation subunits considering local emitter head loss. Irrigation Science, v. 38, p. 147162, 2020. https://doi.org/10.1007/s00271-019-00656-0

WANG, J.; YANG, T.; WEI, T.; CHEN, R.; YUAN, S. Experimental determination of local head loss of non-coaxial emitters in thin-wall lay-flat polyethylene pipes. Biosystems Engineering, v.190, p.71-86, 2020. https://doi.org/10.1016/j.biosystemseng.2019.11.021

WU, I-Pai.; YUE, R. Drip lateral design energy gradient line approach. Transaction of the ASAE, v. 36, n. 2, p. 389-394, 1993.

WU, I. An assessment of hydraulic design of micro-irrigation systems. Agricultural Water Management, v. 32, n. 3, p. 275-284, 1997. https://doi.org/10.1016/S03783774(96)01270-X

YASMINA, L.; RACHID, L. Evaluation of energy losses in pipes. American Journal of Mechanical Engineering, v. 3, p. 32-37, 2015.

YILDIRIM, G. An assessment of hydraulic design of trickle laterals considering effect of minor losses. Irrigation and Drainage, v. 56, p. 399-421. 2007. https://doi.org/10.1002/ird.303 